\title{
Antecedents of Job Satisfaction in Saudi Arabia: Impact of Industrial Sector
}

\author{
Abdulmonem Hamdan Awaad Alzalabani ${ }^{1}$ \\ ${ }^{1}$ Yanbu University College, Saudi Arabia \\ Correspondence: Abdulmonem Hamdan Awaad Alzalabani, Yanbu University College, P.O. Box 30488, Yanbu \\ Industrial City, Saudi Arabia
}

Received: August 28, 2017

Accepted: September 28, 2017

Online Published: October 18, 2017

doi:10.5539/ijbm.v12n11p61

URL: https://doi.org/10.5539/ijbm.v12n11p61

\begin{abstract}
The exhaustive effort of Government of Saudi Arabia to standardize HRM practices across different industrial sectors in the Kingdom is expected to enhance the participation of its nationals in private sectors including SME's. This study is an effort to understand the perceived level of job satisfaction, job stress, work place violence and role clarity after the enforcement of "Nitagat" program and various amendments in the present law to promote employee well being and employee participation in order to enhance job satisfaction.

The study reports a moderately better level of job satisfaction across all respondents but constrained by industry type. In spite of the best efforts of competent authorities to ensure better work environment by amending and designing regulations a significant higher job stress and work place violence is reported in private sector as compared to public sector which has fared better scores on Role clarity and lower scores on work place violence and job stress. As demonstrated through Structural equation model, the relations between job stress, role clarity and work place violence across industry sector (public vs private) further implying that key practices pertaining to HRM still remain a concern to be addressed.
\end{abstract}

Keywords: job stress, job satisfaction, role clarity, workplace violence, Saudi Arabia

\section{Introduction}

Like any other country in the Gulf, Saudi Arabia too has recognized the urgent need to switching its economy away from crude oil production alone to leading world producer of petrochemicals. (Mellahi and Woods,2001; Mellahi,2006). The efforts of the kingdom to dawn a new identity of progressed industrial state has shown a remarkable progress like increase in number of industrial units, growth in GDP despite slump in oil prices to name a few. The efforts exerted by the government for the support of industrial development covered several basic spheres including implementation of required infrastructure, construction of Jubail and Yanbu industrial cities, construction of industrial cities in various regions of the Kingdom, establishment of Saudi Industrial Development Fund (SIDF), and continued provision of other industrial support and incentives.

The urge and keenness of Government of Saudi Arabia for joint ventures and foreign investment in the country could potentially not achieved unless and until reforms are initiated in the conservative Saudi labor market, governed by 1969 Saudi Labor Law which gave employers in the private sector wide latitude to unlawfully exploit and abuse workers.

The labor market in Saudi Arabia is still dominated by expatriates, who are mostly low-skilled workers, even as unemployment rates among young Saudis remain high(Alshanbri et al., 2014; Alzalabani, 2004; Mellahi, 2007). The apathy of its own nationals towards private jobs coupled with fear of exploitation and abuse by private sector may further put a cork in the industrial growth trajectory which the kingdom would seldom like to happen. Growing unemployment on one hand and the religious, social and cultural taboo for private jobs have already made the task more intrinsic for government to ensure welfare and benefits for the existing work force. On the backdrop of this it would be interesting and worth studying the job satisfaction of Saudi national employed in both private and public sector after nearly two decades of Saudization by government and whether the core objective of this Saudization has been fulfilled. General job satisfaction and turnover intentions of public employees are different from those of private employees'. (Mihajlov \& Mihajlov, 2016). 
Job satisfaction is one of the best indicators of prevailing work environment in the organization. While some researchers have reported that public employees are more satisfied, others have shown that satisfaction is higher among private sector employees (Paillé et al., 2015). Numerous studies have stressed that Job satisfaction cannot be viewed in isolation and contribution of various factors such as Work place violence, Job stress and role clarity needs to be acknowledged. As some studies('Sunny'Hu \& Cheng, 2010; Al-Ajmi, 2001; Boyne, Poole, \& Jenkins, 1999)have claimed these factors and their relationships may differ between work places in the private and public sectors, this study will also empirically examine the relationships among these factors and the differences between industrial sectors. The study apart from understanding the perceived level of these antecedents to job satisfaction across various industries tries to take an integrated view of various antecedents of job satisfactions, their relations amongst themselves and their cumulative effect on job satisfaction across various sectors public or private in the rapidly burgeoning Saudi Arabian industrial economy.

\section{Literature Review}

\subsection{Job Satisfaction}

There are several definitions of job satisfaction, such as "a positive (or negative) evaluative judgment one makes about one's job or job situation"(Weiss, 2002, p. 175).Similarly,Robert and Angelo (2007, p. 192) defined job satisfaction as "an affective or emotional response toward various facets of one's job." Many factors have been found to influence job satisfaction, including supervisor support, co-worker support, training opportunities, participation in decision making, and tension at the workplace (Griffiths, Baxter, \& Townley-Jones, 2011).

Recently, some studies have reported a strong negative relationship between job satisfaction and job stress (Ahsan et al., 2009; Griffiths et al., 2011; Klassen \& Chiu, 2010) and with employees' intent to leave (Paillé, Grima, \& Dufour, 2015), as well as positive relationships between job satisfaction and self-efficacy(Klassen \& Chiu, 2010), organizational commitment(Dirani \& Kuchinke, 2011; Top \& Gider, 2013), and organizational citizenship behavior (Paillé et al., 2015). Several factors, such as job stress, role ambiguity, and workplace violence, may hinder individuals from performing their duties effectively(Al-Ajmi, 2001). Griffiths et al. (2011) identified a strong relationship between job stress and job satisfaction. This result is in line with the findings of many studies (Ahsan et al., 2009; Klassen \& Chiu, 2010; Ram et al., 2011; Robert \& Angelo, 2007), all confirming a significant, negative relationship between work stress and job satisfaction. Consequently, job stress has been used as an indicator of the level of job satisfaction(Griffiths et al., 2011) and has been identified as a main source of employee turnover (Alshanbri, Khalfan, \& Maqsood, 2014).

\subsection{Job Stress}

Job stress can be defined as "a situation in which some characteristics of the work situation are thought to cause poor psychological or physical health or to cause risk factors making poor health more likely"(Beehr, 2014, p. 11). Robert and Angelo (2007) argued that individual characteristics and psychological processes may play mediating roles in causing job stress, as they defined stress as "an adaptive response, mediated by individual characteristics and/ or psychological processes, that is a consequence of any external action, situation"(Robert \& Angelo, 2007, p. 599).

Job stress is caused by a lack of support, a lack of perceived control over the work, task characteristics, and work overload('Sunny'Hu \& Cheng, 2010; Griffiths et al., 2011),and role ambiguity or role conflict(Ahsan et al., 2009; Ram et al., 2011; Showail, McLean Parks, \& Smith, 2013).

\subsection{Workplace Violence}

Chappell and Di Martino (2006, p. 10) defined workplace violence as "any action, incident or behavior that departs from reasonable conduct and in which a person is assaulted, threatened, harmed, or injured in the course of or as a direct result of his or her work."

Neuman and Baron (1998, p. 391) considered workplace aggression to be a general term that includes any act by which individuals intentionally attempt to harm others at work or their organizations. Tabassum (2013) stated that job stress can manifest into harmful emotions such as "anxiety, aggression, irritability, dependency, withdrawal or depression" (p. 68), many of which could stimulate violent behaviors in workplace.

\subsection{Role Clarity}

Role clarity "can refer to the presence or absence of adequate role-relevant information due either to restrictions on this information or to variations in the quality of the information"(Lyons, 1971, p. 100). According to Breaugh and Colihan (1994), employees are often unclear about how to do their jobs, when certain tasks should be performed and the criteria by which their performance will be judged. Years of research on role ambiguity has 
shown that it is a noxious state which is associated with negative psychological, physical and behavioral outcomes (Jackson and Schuler 1985).

\subsection{Role Clarity and Job Stress}

Role conflict and role ambiguity are among the antecedents of work stress which have been most cited in the research literature (Fisher \& Gitelson, 1983). Role conflict, that is pressure to perform in two or more incompatible ways, has been tied conclusively to occupational stress in Western research. It has also been demonstrated to be a factor in job dissatisfaction and propensity to leave the organization (Kahn, Wolfe, Quinn, Snoeck \& Rosenthal, 1964; Rizzo, House \& Lirtzman, 1970; House \& Rizzo, 1972; Hamner \& Tosi, 1974; Van Sell, Brief \& Schuler, 1981; Stout \& Posner, 1984; Fang \& Baba, 1993; Cordes \& Dougherty, 1993). Role ambiguity, the lack of clear and specific information regarding work role requirements, has also been linked repeatedly with job stress and low job satisfaction (House \& Rizzo, 1972; Hamner \& Tosi, 1974; Ivancevich \& Donnelly, 1974; Wright \& Thomas, 1982; Cordes \& Dougherty, 1993). Job satisfaction is a result of many factors of which job stress is one of the important antecedent. In general, job stress has been viewed as an antecedent of job satisfaction, and the two constructs have been treated as related yet distinct (Stanton, 2002). An inverse relationship between job stress and job satisfaction among various populations has been reported consistently in the literature (Beehr, 1976) (Cotton, 2002); (Dua, 1994) (Hawe, 2000); (Heslop, 2002) (Lu, 1997); (Richardsen, 1991); (Ulleberg, 1997)

The cause of job stress can be attributed to various organizational and physiological reasons and one of the key contributors of job stress is lack of role clarity. (NSW, 2014)

Role conflict and role ambiguity are positively and significantly related to work stress and work stress was negatively and significantly related to job satisfaction. Kahn, Wolfe, Quinn, Snoek, and Rosenthal (1964) found that ambiguous role expectations (subjective) were associated with greater tension and less job satisfaction than were clear role expectations. Shepard (1969) reported a high negative relationship $(\mathrm{R}=--.47)$ for industrial workers between job satisfaction and an "index of perceived meaninglessness in work. Smith (1957) found unclear roles in laboratory groups resulted in less group productivity in addition to less satisfaction and increased defensiveness. The correlations between role clarity and job tension were significant for both low and high need-for-clarity groups. (LYONS, 1971).

Work stress or job stress caused due to tight deadlines, long hours and worries about the economy. Some jobs are more stressful than others, which puts a great burden on employees. Sometimes stress becomes so overwhelming that violence erupts(Burney, 2015). Tabassum (2013) stated that job stress can manifest into harmful emotions such as "anxiety, aggression, irritability, dependency, withdrawal or depression" (p. 68), many of which could stimulate violent behaviors in workplace. As indicated in Gómez-Mejía, Balkin, and Cardy (2012), a prominent factor contributing to workplace violence is the stress caused either at work or from personal life. One of the out -come of job stress can be in the form of work place violence as documented in the above studies.

In sum it could be inferred that lack of role clarity leads to job stress which may often express itself in work place conflicts and violence leading to reduce job satisfaction.

In comparison with public sector private sector employees were found to be satisfied regarding role clarity. (Brunetto, 2011). Compared to private sector employees, employees in the public sector reported lower level of decision authority and role clarity. ( (Ronald.J.Burke, Noblet, \& Cary, 2013)

The present study tries to use this theoretical base to study the interrelationships among all these variables instead of looking at each individual relation especially in the context of public sector and private sector considering the broader national interest of the Kingdom.

The objectives of this study are as follows:

1- To examine differences in job satisfaction, job stress, Work place violence and role clarity across public and private sector organizations operating in western Saudi Arabia

2- To understand the interrelations of various variables such as job clarity, work place violence and job stress in predicament of job satisfaction across various sectors in Yanbu.

Hence the hypothesis are based on the above studies

$\mathrm{Ho}_{1}$ : The perceived level of job satisfaction, job stress, role clarity and work place violence are associated with nationality and sector of employment in Saudi Arabia.

$\mathrm{Ho}_{2}$ : Variance in job satisfaction can be attributed to job stress, role clarity and Work place violence 
$\mathrm{Ho}_{3}$ : Work place violence and Job stress is positively related.

$\mathrm{Ho}_{4}$ : Work place violence and Job stress are positively related with Role Clarity.

\section{Methodology}

\subsection{Sample}

The respondents in this study were the employees of 11 organizations in the private and public sectors in the western region of Saudi Arabia, particularly Yanbu Industrial City.The sample includes employees from the largest companies in the area which have either private equity holding or public owned conglomerates.

The petrochemical industrial sector includes large corporations, often multinationals; for this study, 4 companies were selected, with a sample size of 207. The public organizations included 4 organizations that provide educational, medical, and municipal services, with a sample size of 219. The third group included 3 SMEs, with sample size of 129. Therefore, 555 usable questionnaires were returned, which represented $71 \%$ of the 780 distributed. Overall there are 7 private and 4 public sector companies included in the study. Table 1 presents the sample characteristics by sector. The large companies were multinational corporations conducting business in the petrochemical industry in Yanbu City and have both administrative and blue-collar employees, including operators and maintenance crews.

\subsection{Instruments of Measurement}

\subsubsection{Job Stress}

The items used to measure job stress were adapted from the job stress questionnaires developed by Roche (2009)and the American Institute of Stress (2015).and included five different statement which measures the different aspect of Job Stress. The respondents are asked to rate some of the statements such as "I find my work stressful", "Find that family gets fed up with the pressure of your job" on a 5 point scale.

\subsubsection{Role Clarity}

Role clarity was measured using a scale developed by George et al. (2010) for three different statement which measures the different aspect of Role Clarity. Some of the statements are "The work I am expected to do is very clearly defined", "What counts as good performance is clearly understood".

\subsubsection{Workplace Violence}

Workplace violence was measured using a questionnaire developed by Quine (1999) for three different statement which measures the different aspect of Workplace Violence. The respondents are asked to "I tend to have frequent arguments with superiors, co workers or customers", "I have the impression that I am repeatedly picked on off discriminated against at work".

\subsubsection{Job Satisfaction}

The author used a five-item scale developed by Roche (2009). Four domains and general employee satisfaction were included: work conditions, hours of work, earnings, and perceived work interest. Some of the statements in this section "In general I am satisfied with my present work"; "I find my work interesting"; "I am satisfied with my earnings from present job"

\section{Results}

The survey participants included 555 employees from 11 organizations. Table 1 presents the results of the demographic analysis. The analysis of the data in this paper is structured in two parts. The first part attempts to assess the perceived overall levels of job stress, role clarity, workplace violence, and job satisfaction. The second part examines the relationships between these factors through SEM and direct and indirect effects of the antecedents of job satisfaction with various control variables. As observed from table 1, among the subjects, $36.6 \%$ were $20-30$ years old, $38.4 \%$ were $31-40$ years old, $19.1 \%$ were $41-50$ years old, and $5.9 \%$ were $51-60$ years old. In addition, $76.2 \%$ were Saudis and $71.4 \%$ were married. The majority of participants were university graduates, with $47.7 \%$ holding a bachelor's degree and $10.3 \%$ holding a master's degree or higher. 
Table 1. Characteristics of sample $(\mathrm{N}=555)$

\begin{tabular}{|c|c|c|c|c|c|c|c|c|c|}
\hline \multirow[b]{3}{*}{ Characteristics } & \multirow[b]{3}{*}{ Categories } & \multirow{3}{*}{$\begin{array}{l}\text { All } \\
\text { count }\end{array}$} & \multicolumn{4}{|c|}{ Sector } & \multirow[b]{2}{*}{ SMEs } & \multirow{3}{*}{ count } & \multirow[b]{3}{*}{$\%$} \\
\hline & & & & Large & Public & & & & \\
\hline & & & $\%$ & count & $\%$ & count & $\%$ & & \\
\hline \multirow{4}{*}{ Age } & $20-30$ years & 203 & 36.6 & 89 & 43 & 54 & 24.7 & 60 & 46.5 \\
\hline & $31-40$ years & 213 & 38.4 & 61 & 29.5 & 84 & 38.4 & 68 & 52.7 \\
\hline & $41-50$ years & 106 & 19.1 & 35 & 16.9 & 70 & 32 & 1 & 0.8 \\
\hline & $51-60$ years & 33 & 5.9 & 22 & 10.6 & 11 & 5 & 0 & 0 \\
\hline \multirow{2}{*}{ Nationality } & Saudi & 423 & 76.2 & 148 & 71.5 & 178 & 81.3 & 97 & 75.2 \\
\hline & Non-Saudi & 132 & 23.8 & 59 & 28.5 & 41 & 18.7 & 32 & 24.8 \\
\hline \multirow{2}{*}{ Marital status } & Single & 159 & 28.6 & 64 & 30.9 & 31 & 14.2 & 64 & 49.6 \\
\hline & Married & 396 & 71.4 & 243 & 69.1 & 188 & 85.8 & 65 & 50.4 \\
\hline \multirow{4}{*}{ Qualification } & $\begin{array}{l}\text { High } \quad \text { school } \\
\text { degree }\end{array}$ & 121 & 21.9 & 32 & 15.6 & 51 & 23.3 & 38 & 29.5 \\
\hline & $\begin{array}{l}\text { Associate's } \\
\text { degree }\end{array}$ & 111 & 20.1 & 48 & 23.4 & 38 & 17.4 & 25 & 19.4 \\
\hline & $\begin{array}{l}\text { Bachelor's } \\
\text { degree }\end{array}$ & 264 & 47.7 & 104 & 50.7 & 96 & 43.8 & 64 & 49.6 \\
\hline & $\begin{array}{l}\text { Master's degree } \\
\text { or higher }\end{array}$ & 57 & 10.3 & 21 & 10.2 & 34 & 15.5 & 2 & 1.6 \\
\hline
\end{tabular}

\subsection{Rates of Job Stress, Role Clarity, Workplace Violence, and Job Satisfaction}

Table 2 presents the means and standard deviations for job stress, role clarity, workplace violence, and job satisfaction. Job stress is somewhat high, with $\mathrm{M}=2.96$, while workplace violence is low, with $\mathrm{M}=2.35$. Conversely, role clarity and job satisfaction scored high, with $\mathrm{M}=3.53$ and 3.35 , respectively. It seems that apart from job stress other outcomes of prudent HR practices such as role clarity and job satisfaction to be satisfactory. But it worthwhile to investigate further that such satisfactory levels represent the entire industrial scenario or does it varies according to ownership such as public and private sector organization. More specifically, $56 \%$ of the respondents reported finding their job stressful $(M=3.28)$, and the same percentage said they return home from work exhausted $(\mathrm{M}=3.31)$. Additionally, 54\% thought their jobs were characterized by high responsibility but low authority. The workplace environment was not found to be pleasant or particularly safe by $52 \%$ of the respondents. Moreover, $55.4 \%$ of participants stated they have frequent arguments with superiors, coworkers, or customers and 52\% felt they had very little control over their life at work.

In addition, the level of workplace violence in the surveyed firms was found to be low. Among the 21 items tested, only 7 variables had scores above 2.5. These included overwork $(\mathrm{M}=2.74)$; unreasonable refusal on applications for leave, training, or promotion $(\mathrm{M}=2.64)$; persistent attempts to belittle and undermine the target's work $(M=2.57)$; persistent unjustified criticism $(M=2.56)$; withholding necessary information $(M=2.55)$; and shifting of goal posts without informing the target $(\mathrm{M}=2.53)$.

Table 2.Descriptive statistics $(\mathrm{N}=555)$

\begin{tabular}{lll}
\hline Variables & Mean & SD \\
\hline Job stress & 2.96 & .83 \\
Role clarity & 3.53 & .93 \\
Violence level & 2.35 & .94 \\
Job satisfaction & 3.35 & .98 \\
\hline
\end{tabular}

Differences in Job satisfaction, Job stress, role clarity and Workplace Violence according to Sector and Nationality

As one of the objectives of this research article is to review and compare differences in job satisfaction and precedents of sound HR practices such as Job stress, Role clarity and Workplace violence we inquire differences in mean score of these constructs according to sector such as public or private. A t test is used to understand the differences in scores amongst these constructs which are tabulated in table 3. It is observed that role clarity and job satisfaction levels does not differ significantly in public and private sector whereas significant differences in 
work place violence and job stress are recorded across public and private sector. Further the level of job stress and work place violence are comparatively higher in private sector as compared to public sector. Though one of the objectives of nationalization program was to ensure enhanced participation of Saudi nationals equally it was important that no discrimination between expatriates and Saudi nationals shall emanate from the nationalization program as it would seriously hamper the image and prospects of the Kingdom to position itself as a global destination for technology, manufacturing and tourism. A $t$ test was conducted to understand the difference in perception in regards to Job satisfaction, Job stress, and work place violence according to nationality. Table 4 revealed that no significant differences in job satisfaction levels, role clarity and work place violence are reported between Saudi and expatriate labor force.

\subsection{Interrelationship of Various Antecedents of Job Satisfaction}

In this analysis, after removing missing value data sample size was reduced to 545 . The output as demonstrated in table 5 shows that, model is perfectly fit with chi square $=3.43, \mathrm{df}=2, \mathrm{p}=0.179$ and moreover the ratio of Chi square/ $\mathrm{df}=1.71$, further substantiates that model obtained is an excellent fit

Further, the fit indices indicate perfect fit between observed data and the model, standardized estimates of parameters are provided in analysis.

In this analysis fit criteria of Maximum likelihood method was used. It is a iterative process where prediction could be correct and it's depend upon maximization of likelihood of criterion variable.

On observing the regression coefficients from table 6 we infer that variation in Job stress is attributed to sector whether public or private company. Surprisingly a non significant coefficient surfaced for prediction in job stress in lieu of role clarity. Further as corroborated in the literature job satisfaction shall be driven by lower job stress, lower work place violence and much higher level of role clarity. One of the facts that warrant attention is that higher work place violence is reported in private sector as compared to public sector.

Table 3. Difference in Job stress, Job satisfaction, Role Clarity and WPV in different sector

\begin{tabular}{lllll}
\hline Construct & $\mathrm{F}$ & Sign & $\mathrm{t}$ & Sign \\
\hline Job stress & 4.652 & 0.031 & -3.220 & $0.001^{*}$ \\
Role Clarity & 7.706 & 0.006 & -0.203 & 0.839 \\
Work place Violence & 1.090 & 0.297 & -5.728 & $0.000^{* *}$ \\
Job satisfaction & 4.373 & 0.037 & 0.896 & 0.371 \\
\hline
\end{tabular}

\subsection{Model Fit Indices}

This model was validated using chi-square, obtaining a value of $3.43(\mathrm{df}=2), \mathrm{p}=0.179$ (This test compares the best model to a full (saturated) model; a non-significant chi-square is therefore desirable). For this test, a ratio of chi-square to df which is equal to or smaller than 3 is considered acceptable (Schreiber et al., 2006).

This model is an excellent fit, due to following values $\mathrm{RMR}=0.019$, GFI $=0.997$, AGFI $=0.981$, NFI $=0.989$, TLI $=0.976$, CFI $=0.995$, RMSEA $=0.036$, HOELTER $=949, \mathrm{p}=0.05$

Table 4. Level of Job stress, Job satisfaction and WPV across nationality

\begin{tabular}{lllll}
\hline Construct & $\mathrm{F}$ & Sign & $\mathrm{t}$ & Sign \\
\hline Job stress & 0.392 & 0.532 & 3.123 & $0.002^{*}$ \\
Role Clarity & 1.124 & 0.290 & -1.757 & 0.079 \\
Work place Violence & 0.943 & 0.332 & 0.323 & 0.747 \\
Job satisfaction & 0.439 & 0.508 & -1.549 & 0.122 \\
\hline
\end{tabular}

\subsection{Path Diagram}

Figure 1 presents the Standardized Path Diagram, indicating the various statistical relationships between Job Stress, Job Clarity, Work Place Violence, Industry Type and Job Satisfaction in terms of Standardized Coefficient Values and $\mathrm{R}^{2}$. Job stress is found to have a negative relationship with job satisfaction and such relationship is significant as reported by $\mathrm{P}$ value. Role Clarity is significantly and positively related with Job Satisfaction with its correlation coefficient value and it is significant enough as the P value is .000 which is less than $0.055 \%$ level of significance. Work Place Violence is positively related with Job Stress with its correlation 
coefficient which is significant enough. As observed from table 7, 27\% of variance in job satisfaction can be attributed to factors such as work place violence, job stress and role clarity. The highest contributor amongst all variables in this study to job satisfaction is Role clarity followed by job stress which accounts for $21 \%$ variance. $14 \%$ variance in job stress can be attributed to sector difference such as public or private ownership but on other hand the regression weight is non-significant for job stress and role clarity relationship. A significant regression relationship is noted for workplace violence and job stress where job stress accounts for $38 \%$ variance whereas sector public or private contribute to $14 \%$ variance.

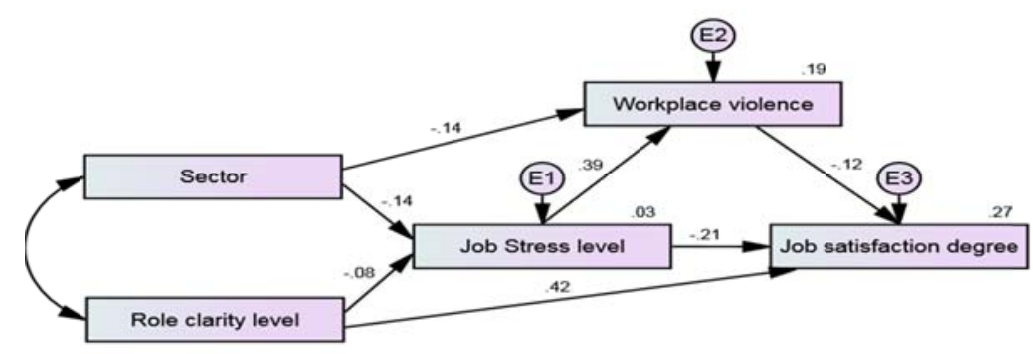

Figure1. Standardized Path Diagram

Table 5. Model fit indices

\begin{tabular}{lll}
\hline Indices & Recommended Value & Model Fit Indices \\
\hline CMIN/df & $<3$ & 1.718 \\
p-value & $\geq 0.05$ & .000 \\
GFI & $\geq 0.90$ & 0.997 \\
AGFI & $\geq 0.80$ & .0 .981 \\
NFI & $\geq 0.90$ & 0.989 \\
CFI & $\geq 0.90$ & 0.995 \\
RMSEA & $\leq 0.08$ & 0.03 \\
P Close & $\geq 0.05$ & .000 \\
\hline
\end{tabular}

Job Stress and Work Place Violence are reporting a positive and significant relationships Further, though Work place violence and Job Stress is positively related with Role Clarity, they are not significantly related as their P value is greater than 0.05 for $5 \%$ level of significance.

Table 6. Standardized Regression Weights

\begin{tabular}{|c|c|c|c|c|c|c|c|}
\hline & & & Estimate & S.E. & C.R. & $\mathrm{P}$ & Remark \\
\hline Jobstress 2 & $<---$ & Sector & -.253 & .076 & -3.343 & $* * *$ & significant \\
\hline Jobstress 2 & $<---$ & Roleclarity2 & -.075 & .037 & -2.001 & .045 & Non significant \\
\hline Tviolence2 & $<---$ & Jobstress 2 & .417 & .042 & 9.917 & $* * *$ & significant \\
\hline Tviolence2 & $<---$ & Sector & -.271 & .075 & -3.604 & $* * *$ & significant \\
\hline Jobsatisfaction2 & $<---$ & Tviolence2 & -.138 & .045 & -3.054 & .002 & Non significant \\
\hline Jobsatisfaction 2 & $<---$ & Jobstress 2 & -.254 & .049 & -5.198 & $* * * *$ & significant \\
\hline Jobsatisfaction 2 & $<---$ & Roleclarity2 & .446 & .039 & 11.295 & $* * * *$ & significant \\
\hline
\end{tabular}

The $\mathrm{R}^{2}$ indicates the variation in the dependent variable (job satisfaction) based on the variations in the independent variables. In the Path diagram of Fig $1, \mathrm{R}^{2}$ indicates job stress, role clarity, and workplace violence account for $27 \%$ of the total variation in job satisfaction. 
Table 7. Standardized Regression Weights

\begin{tabular}{llll}
\hline & & & Estimate \\
\hline Jobstress2 & $<---$ & Sector & -.141 \\
Jobstress2 & $<---$ & Roleclarity2 & -.085 \\
Tviolence2 & $<--$ & Jobstress2 & .388 \\
Tviolence2 & $<--$ & Sector & -.141 \\
Jobsatisfaction2 & $<---$ & Tviolence2 & -.122 \\
Jobsatisfaction2 & $<---$ & Jobstress2 & -.209 \\
Jobsatisfaction2 & $<---$ & Roleclarity2 & .415 \\
\hline
\end{tabular}

\section{Discussion}

The intense efforts of Kingdom of Saudi Arabia to ensure standardization of HRM practices across private sector in order to ensure enhanced participation of its citizens in private sector mandates sound Human resource management practices in order to ensure enhanced work satisfaction with decrease in stress and work place violence. A significant percentage of respondents (54\%) reporting about abuse of Human Resource Management practices. This study's results call for private sector organizations to make significant changes to their human resources practices in order to improve job satisfaction and job performance(Ahsan et al., 2009; Tlaiss \& Mendelson, 2014).The results also confirm Mellahi (2007)argument that some private sector employers exploit and abuse their workers. This problem may be aligned to the comparatively higher in both large and small organizations in private sector as compared to public sector. Accordingly, organizations should also conform to the Saudi labor law and its rules and regulations regarding workload, fringe benefits, employee development opportunities, etc.

Examining the relationship between the selected antecedents of job satisfaction indicated strong associations among all of the factors. Job stress and workplace violence are negatively associated with job satisfaction such that if the first two factors increase, then job satisfaction will decrease. On the contrary, role clarity and job satisfaction are positively associated with each other, such that if one increases, the other also increases.

This study's findings are in line with the results of previous studies(Ahsan et al., 2009; Griffiths et al., 2011; Ram et al., 2011; Robert \& Angelo, 2007; Sofield \& Salmond, 2003) in different locations and different cultures, which confirms the importance of HRM practices in any organization.

Additionally, the results indicated employees in public organizations are not exposed to workplace violence to the same degree as their counterparts in private organizations In relation to this finding, it should be noted that the workplace violence behaviors vary among these groups, according to the respondents. While the most common factors reported by employees in large petrochemical organizations were (1) unreasonable refusal of applications for leave and problems with training or promotion, (2)overwork, and (3) withholding necessary information, in public organizations, the most common factors were(1) overwork,(2) undue pressure to work, and (3) persistent unjustified criticism and monitoring of the individual's work. In addition, the most correlated factors with incidences of violence were 1) shifting of the goal posts without telling the worker,2) undue pressure to work, and3) overwork. It appears that the most common attribute of workplace violence is job stress leadership practices of the work environment or immediate supervisor. This result is similar to the findings from the study byGalanaki and Papalexandris (2013) in Greece. Finally, verbal and non-verbal threats and physical violence were considered very rare occurrences of workplace violence in these organizations.

\section{Conclusion}

The study reports a moderately better level of job satisfaction across all respondents but constrained by higher levels of job stress and work place violence across sector type. In spite of the best efforts of competent authorities a significantly higher job stress and work place violence is still found to be in private sector as compared to public sector which has fared better scores on work place violence and job stress. As demonstrated through Structural equation model, a positive relation between role clarity and job satisfaction and negative relationship between work place violence, job stress and job satisfaction further implies that key HRM practices pertaining to private sector still remain a concern to be addressed.

The respondents indicated they are satisfied with their jobs and perceive their roles to be very clear. They also reported that the occurrence of violence is very rare in their workplaces. However, they admitted to having some forms of job stress. 
The results of the present study are consistent with those of previous studies in that job satisfaction is moderated by factors such as job stress, role clarity, and workplace violence(Ahsan et al., 2009; Griffiths et al., 2011)based on a statistically significant multiple correlation $(\mathrm{R}=.526)$, and these factors are responsible for approximately $28 \%$ of the variation in job satisfaction.

The findings also indicate that organizational items such as job stress and workplace violence vary across industrial sectors. For example, job stress is more prevalent among employees in the private sector (SMEs and large organizations) more than in the public sector, which may be related to the existence of different rules and regulations. Of note, overwork was cited as one of the three major acts of workplace violence in all three sectors, while physical violence was rated as the least common act of workplace aggression. This study adds valuable knowledge because it tries to integrate the various determinants of job satisfaction such as role clarity, work place violence and job stress across public and private sector. It is critical for employees and management to be able to diagnose the existence of workplace violence or other counter-productive behaviors so that the necessary steps can be taken (Branch, 2008).

If the intensity and pace of industrialization is ought to be maintained it is imperative for the government to ensure that private sector in line with public sector maintains a acceptable work culture where employees should not feel marginalized and vindicated. The study has brought to forefront key issues such as Work place violence and Job stress which needs to be addressed by the private sector as sufficient evidence of their existence as compared to public sector is found in private sector.

\section{Limitations and Future Research}

This study has several limitations that should be considered in future studies. First, the potential for respondent bias combined with difficulty accessing the target population may constrain the study's generalization. Second, the survey was limited to one region of Saudi Arabia due to the location of such organizations. Moreover the role of various variables such as socio demographic attributes of the respondents could be incorporated to consider their role as moderator or mediators in such a relationship. Though role clarity, work place violence and job stress account for variance in job satisfaction a moderately higher unexplained variance still remains unaccounted and various other variables could be incorporated to attribute this unaccounted variation. Future studies could explore job stress, role clarity, workplace violence, and job satisfaction in other Saudi cities or regions to help to understand the case of the Saudi work environment. Additionally, future studies should focus on measuring the quality of work life in these sectors.

\section{References}

'Sunny'Hu, H. H., \& Cheng, C. W. (2010). Job stress, coping strategies, and burnout among hotel industry supervisors in Taiwan. The International Journal of Human Resource Management, 21(8), 1337-1350. https://doi.org/10.1080/09585192.2010.483867

Ahsan, N., Abdullah, Z., Fie, D. G., \& Alam, S. S. (2009). A study of job stress on job satisfaction among university staff in Malaysia: Empirical study. European journal of social sciences, 8(1), 121-131.

Al-Ajmi, R. (2001). The effect of personal characteristics on job satisfaction: A study among male managers in the Kuwait oil industry. International Journal of Commerce and Management, 11(3/4), 91-110. https://doi.org/10.1108/eb047429

Al-Hajri, S. H. (1994). Job characteristics, job satisfaction, work-related values, organizational commitment, and job involvement among Saudi workers in the private sector. (Doctoral dissertation, Lowa State University, 1994).

Allen, I. E., \& Seaman, C. A. (2007). Likert scales and data analyses. Quality Progress, 40(7), 64-65.

Alshanbri, N., Khalfan, M., \& Maqsood, T. (2014). Nitaqat program in Saudi Arabia. International Journal of Innovative Research in Advanced Engineering, 1(10), 357-366.

Alzalabani, \& Nair, R. D. (2011). Employee empowerment and job satisfaction: A case study of RC and Sabic in the Kingdom of Saudi Arabia. International Employment Relations Review, 17(1), 21.

Alzalabani, A. (2004). Industrial relations and labor market in Saudi Arabia. Paper presented at the Conference of the International Industrial Relations Association (IIRA), Seoul, Korea.

Alzalabani, A. (2012). Employee Voice Mechanisms in The Kingdom of Saudi Arabia. 산업관계연구, 22(1), 145-176.

American Institute of Stress. (2015). Workplace Stress Survey. Retrieved from http://www.stress.org 
Ansoleaga, E., Montaño, R., \& Vézina, M. (2013). Validation of two complementary instruments for measuring work stress in Chilean workers. Scandinavian Journal of Organizational Psychology, 5(2), 5-14.

Baron, R. A., \& Neuman, J. H. (1996). Workplace violence and workplace aggression: Evidence on their relative frequency and potential causes. Aggressive behavior, 22(3), 161-173. https://doi.org/10.1002/(SICI)1098-2337(1996)22:3<161::AID-AB1>3.0.CO;2-Q

Bayt.com. (2015). Job Satisfaction Report in the Middle East and North Africa. Retrieved on 10 April 2015 , from http://www.img.b8cdn.com/images/uploads/article_docs/bayt_job-satisfaction_report

Beehr, T. A. (2014). Psychological Stress in the Workplace (Psychology Revivals). New York: Routledge.

Boyne, G., Poole, M., \& Jenkins, G. (1999). Human resource management in the public and private sectors: An empirical comparison. Public Administration, 77(2), 407-420. https://doi.org/10.1111/1467-9299.00160

Branch, S. (2008). You say tomatoe and I say tomato: Can we differentiate between workplace bullying and other counterproductive behaviours. International Journal of Organisational Behaviour, 13(2), 4-17.

Budhwar, P. S., \& Boyne, G. (2004). Human resource management in the Indian public and private sectors: an empirical comparison. The International Journal of Human Resource Management, 15(2), 346-370. https://doi.org/10.1080/0958519032000158554

Carifio, J., \& Perla, R. J. (2007). Ten common misunderstandings, misconceptions, persistent myths and urban legends about Likert scales and Likert response formats and their antidotes. Journal of Social Sciences, 3(3), 106-116. https://doi.org/10.3844/jssp.2007.106.116

Chappell, D., \& Di Martino, V. (2006). Violence at work (3rd ed.). Geneva: International Labour Organization.

De Guinea, A. O., \& Webster, J. (2012). The missing links: cultural, software, task and personal influences on computer self-efficacy. The International Journal of Human Resource Management, 23(ahead-of-print), $1-27$.

De Jonge, J., Bosma, H., Peter, R., \& Siegrist, J. (2000). Job strain, effort-reward imbalance and employee well-being: a large-scale cross-sectional study. Social Science \& Medicine, 50(9), 1317-1327. https://doi.org/10.1016/S0277-9536(99)00388-3

Dirani, K. M., \& Kuchinke, K. P. (2011). Job satisfaction and organizational commitment: validating the Arabic satisfaction and commitment questionnaire (ASCQ), testing the correlations, and investigating the effects of demographic variables in the Lebanese banking sector. The International Journal of Human Resource Management, 22(5), 1180-1202. https://doi.org/10.1080/09585192.2011.556801

Dodin, H. (2010). Advance Statistical Analysis of data using SPSS. Jordain: Massira.

Drabe, D., Hauff, S., \& Richter, N. F. (2015). Job satisfaction in aging workforces: An analysis of the USA, Japan and Germany. The International Journal of Human Resource Management, 26(6), 783-805. https://doi.org/10.1080/09585192.2014.939101

Galanaki, E., \& Papalexandris, N. (2013). Measuring workplace bullying in organisations. The International Journal of Human Resource Management, 2107-2130. https://doi.org/10.1080/09585192.2012.725084

George, E., Levenson, A., Finegold, D., \& Chattopadhyay, P. (2010). Extra-role behaviors among temporary workers: how firms create relational wealth in the United States of America. The International Journal of Human Resource Management, 21(4), 530-550. https://doi.org/10.1080/09585191003612034

Griffiths, M. F., Baxter, S. M., \& Townley-Jones, M. E. (2011). The Wellbeing of Financial Counselors: A Study of Work Stress and Job Satisfaction. Journal of Financial Counseling and Planning, 22(2), 41-53.

Hayes, B., Douglas, C., \& Bonner, A. (2015). Work environment, job satisfaction, stress and burnout among haemodialysis nurses. Journal of nursing management, 23(5), 588-598. https://doi.org/10.1111/jonm.12184

Ivancevich, J. M., \& Matteson, M. (1990). Organizational Behavior and Management (10th ed.). New York, NY: McGraw-Hill.

Job Watch. (2005). Workplace Violence and bullying. Job Watch and Worksafe Victoria.

Karasek, J. R. A. (1979). Job demands, job decision latitude, and mental strain: Implications for job redesign. Administrative Science Quarterly, 24, 285-308. https://doi.org/10.2307/2392498 
Klassen, R. M., \& Chiu, M. M. (2010). Effects on teachers' self-efficacy and job satisfaction: Teacher gender, years of experience, and job stress. Journal of Educational Psychology, 102(3), 741-756. https://doi.org/10.1037/a0019237

Kowalenko, T., Walters, B. L., Khare, R. K., Compton, S., \& Force, M. C. O. E. P. W. V. T. (2005). Workplace violence: a survey of emergency physicians in the state of Michigan. Annals of Emergency Medicine, 46(2), 142-147. https://doi.org/10.1016/j.annemergmed.2004.10.010

Lange, T., Pacheco, G., \& Shrotryia, V. K. (2010). Culture, industrialisation and multiple domains of employees' job satisfaction: a case for HR strategy redesign in India. The International Journal of Human Resource Management, 21(13), 2438-2451. https://doi.org/10.1080/09585192.2010.516595

Lee, L. Y., \& Sukoco, B. M. (2010). The effects of cultural intelligence on expatriate performance: The moderating effects of international experience. The International Journal of Human Resource Management, 21(7), 963-981. https://doi.org/10.1080/09585191003783397

Lyons, T. F. (1971). Role clarity, need for clarity, satisfaction, tension, and withdrawal. Organizational Behavior and Human Performance, 6(1), 99-110. https://doi.org/10.1016/0030-5073(71)90007-9

Mellahi, K. (2007). The effect of regulations on HRM: private sector firms in Saudi Arabia. The International Journal of Human Resource Management, 18(1), 85-99. https://doi.org/10.1080/09585190601068359

Metle, M. A. K. (2001). Education, job satisfaction and gender in Kuwait. International Journal of Human Resource Management, 12(2), 311-332. https://doi.org/10.1080/09585190122366

Neuman, J. H., \& Baron, R. A. (1998). Workplace violence and workplace aggression: Evidence concerning specific forms, potential causes, and preferred targets. Journal of management, 24(3), 391-419. https://doi.org/10.1177/014920639802400305

Norman, G. (2010). Likert scales, levels of measurement and the "laws" of statistics. Advances in health sciences education, 15(5), 625-632. https://doi.org/10.1007/s10459-010-9222-y

Paillé, P., Grima, F., \& Dufour, M.-È. (2015). Contribution to social exchange in public organizations: examining how support, trust, satisfaction, commitment and work outcomes are related. The International Journal of Human Resource Management, 26(4), 520-546. https://doi.org/10.1080/09585192.2012.654809

Quine, L. (1999). Workplace bullying in NHS community trust: staff questionnaire survey. Bmj, 318(7178), 228-232. https://doi.org/10.1136/bmj.318.7178.228

Ram, N., Khoso, I., Shah, A. A., Chandio, F. R., \& Shaikih, F. M. (2011). Role conflict and role ambiguity as factors in work stress among managers: A case study of manufacturing sector in Pakistan. Asian Social Science, 7(2), 113. https://doi.org/10.5539/ass.v7n2p113

Rayton, B. A., \& Yalabik, Z. Y. (2014). Work engagement, psychological contract breach and job satisfaction. The International Journal of Human Resource Management, 25(17), 2382-2400. https://doi.org/10.1080/09585192.2013.876440

Robert, K., \& Angelo, K. (2007). Organization behavior (7th ed.). New York: McGraw-Hill.

Roche, W. K. (2009). Who gains from workplace partnership? The International Journal of Human Resource Management, 20(1), 1-33. https://doi.org/10.1080/09585190802528219

Showail, S. J., McLean Parks, J., \& Smith, F. L. (2013). Foreign workers in Saudi Arabia: a field study of role ambiguity, identification, information-seeking, organizational support and performance. The International Journal of Human Resource Management, 24(21), 3957-3979. https://doi.org/10.1080/09585192.2013.781521

Siegrist, J., Wege, N., Pühlhofer, F., \& Wahrendorf, M. (2009). A short generic measure of work stress in the era of globalization: effort-reward imbalance. International Archives of Occupational and Environmental Health, 82(8), 1005-1013. https://doi.org/10.1007/s00420-008-0384-3

Sofield, L., \& Salmond, S. W. (2003). Workplace violence: A focus on verbal abuse and intent to leave the organization. Orthopaedic Nursing, 22(4), 274-283. https://doi.org/10.1097/00006416-200307000-00008

Swaminathan, S., \& Jawahar, P. D. (2013). Job Satisfaction as A Predictor of Organizational Citizenship Behavior: An Empirical Study. Global Journal of Business Research (GJBR), 7(1), 71-80. 
Tlaiss, H. A., \& Mendelson, M. B. (2014). Predicting women's job satisfaction with personal demographics: evidence from a Middle Eastern country. The International Journal of Human Resource Management, 25(3), 434-458. https://doi.org/10.1080/09585192.2013.792859

Top, M., \& Gider, O. (2013). Interaction of organizational commitment and job satisfaction of nurses and medical secretaries in Turkey. The International Journal of Human Resource Management, 24(3), 667-683. https://doi.org/10.1080/09585192.2012.680600

Tourigny, L., Baba, V. V., \& Wang, X. (2010). Burnout and depression among nurses in Japan and China: The moderating effects of job satisfaction and absence. The International Journal of Human Resource Management, 21(15), 2741-2761. https://doi.org/10.1080/09585192.2010.528656

Tsutsumi, A., Iwata, N., Watanabe, N., De Jonge, J., Pikhart, H., Fernandez-Lopez, J. A., . . Niedhammer, I. (2009). Application of item response theory to achieve cross-cultural comparability of occupational stress measurement. International Journal of Methods in Psychiatric Research, 18(1), 58. https://doi.org/10.1002/mpr.277

Weiss, H. M. (2002). Deconstructing job satisfaction: Separating evaluations, beliefs and affective experiences. Human Resource Management Review, 12(2), 173-194. https://doi.org/10.1016/S1053-4822(02)00045-1

Wood, R. E. (1986). Task complexity: Definition of the construct. Organizational behavior and human decision processes, 37(1), 60-82. https://doi.org/10.1016/0749-5978(86)90044-0

\section{Copyrights}

Copyright for this article is retained by the author(s), with first publication rights granted to the journal.

This is an open-access article distributed under the terms and conditions of the Creative Commons Attribution license (http://creativecommons.org/licenses/by/4.0/). 